\title{
Efektivitas Pembelajaran Daring Siswa Sekolah Dasar di Masa Pandemi
}

\author{
Anggela Ermitha Anjelin ${ }^{1}$, Heru Purnomo² \\ Universitas PGRI Yogyakarta \\ E-mail:ermithaanjelin@gmail.com, user1@upy.ac.id
}

\begin{abstract}
Article Info
Article History

Received: 2021-03-02

Revised: 2021-06-10

Published: 2021-06-17
\end{abstract}

Keywords:

Effectiveness;

Study;

On line;

Pandemic.

\begin{abstract}
The purpose of this study was to determine the effectiveness of online learning in elementary school children during the pandemic, the factors that support and hinder students and teachers in carrying out online learning. The method used in this research is literature study. The literature review method was used to find and obtain existing data, as well as some detailed explanations about the effectiveness of online learning. Data collection was carried out through an approach to the subject so that it was more in-depth to search for data and was assisted by some previous supporting data. The results of this study can be concluded that the online learning process (on the network) has not been effective and not optimal due to several obstacles such as lack of facilities and infrastructure, unsupported networks, and lack of science and technology knowledge.
\end{abstract}

\begin{tabular}{l}
\hline Artikel Info \\
\hline Sejarah Artikel \\
Diterima: 2021-06-02 \\
Direvisi: 2021-06-10 \\
Dipublikasi: 2021-06-17
\end{tabular}

Kata kunci:

Efektivitas;

Belajar;

Online;

Pandemik.

\begin{abstract}
Abstrak
Penelitian ini bertujuan untuk mengetahui efektifitas pembelajaran online pada anak sekolah dasar pada masa pandemi, faktor-faktor yang mendukung dan menghambat siswa dan guru dalam melaksanakan pembelajaran online. Metode yang digunakan dalam penelitian ini adalah studi pustaka. Metode literature review digunakan untuk mencari dan memperoleh data yang ada, serta beberapa penjelasan rinci tentang efektifitas pembelajaran online. Pengambilan data dilakukan melalui proses pendekatan dengan subjek sehingga lebih mendalam untuk mencari data dan dibantu oleh beberapa data pendukung sebelumnya. Hasil penelitian ini dapat disimpulkan bahwa proses pembelajaran yang dilakukan secara online (on the network) belum efektif dan belum optimal karena beberapa kendala seperti kurangnya sarana dan prasarana, jaringan yang tidak mendukung, dan kurangnya pengetahuan tentang iptek.
\end{abstract}

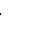


ditentukan, memberikan kesan atau pesan belajar yang menarik, membawa siswa secara aktif, sehingga dapat mendukung pencapaian tujuan instruksional dan memiliki banyak fasilitas yang mendukung proses belajar mengajar. proses. Rohmawati, 2015).

Menurut pandangan Miarso tentang efektivitas yaitu (Rohmawati, 2015:16) "Efektivitas pembelajaran merupakan salah satu standar mutu pendidikan yang sering diukur dengan pencapaian tujuan, atau dapat juga diartikan sebagai ketepatan dalam mengelola suatu keadaan. yang dilakukan oleh setiap sekolah pada masa pandemi saat ini umumnya menggunakan sistem online yang dilakukan di rumah dengan bantuan dan bimbingan orang tua di rumah. Beberapa hal yang direkomendasikan pemerintah dalam merantas rantai penularan Covid-19 melalui pnerapan 3M menggunakan masker, mencuci tangan, dan menjaga jarak.

Dengan adanya wabah virus corona yang menuntut dan memaksa seluruh siswa untuk melakukan pembelajaran secara online, serta diharuskan menggunakan berbagai media dan alat komunikasi untuk menunjang keberhasilan pembelajaran di masa pandemi. Pada umumnya aktivitas pembelajaran dilaksanakan oleh sekolah melalui bimbingan guru. Kusnandar (dalam Alawiyah, 2013: 67) menyampaikan: Guru merupakan garda terdepan dalam penyelenggaraan pendidikan di Indonesia. Keberhasilan dan keberhasilan pendidikan ada di tangan guru. Guru adalah individu yang berhadapan langsung dengan siswa di dalam kelas dalam melaksanakan kegiatan pembelajaran. Guru memiliki peran yang sangat penting dalam membentuk karakter siswa melalui kegiatan belajar mengajar, dimana guru dituntut untuk dapat memberikan pengetahuan, pemahaman, pemahaman, dan hal penting lainnya untuk menghasilkan anak yang berkualitas, berintegritas, dan terampil dalam berbagai bidang. Dalam memenuhi kriteria di atas, diperlukan seorang guru yang memiliki kualifikasi, kompetensi, dan dedikasi dalam melaksanakan tugasnya. Kegiatan belajar mengajar yang dilakukan oleh guru dan siswa biasanya dilakukan di sekolah tanpa melalui perantara seperti handphone, atau surat pemberitahuan, sehingga dalam proses belajar mengajar pun terjadi interaksi langsung yang terjadi dalam proses pembelajaran. Seperti yang kita ketahui, sudah setahun sejak COVID-19 masuk dan berkembang di Indonesia. Oleh karena itu, tugas guru mengalami perubahan dalam proses pembelajaran yaitu memberikan tugas secara online. Tujuan dari penelitian ini adalah untuk mengetahui efektifitas pembelajaran online pada masa pandemi terhadap pelaksanaan pembelajaran yang sebenarnya di sekolah

\section{METODE PENELITIAN}

Metode yang digunakan peneliti dalam meneliti adalah metode literature review. Sumber data diperoleh dari guru dan siswa yang berdomisili di wilayah SP F Mensiku Kecamatan Binjai Hulu
Kabupaten Sintang. Pengumpulan data dilakukan dengan teknik wawancara. Data tersebut dapat dianalisis secara deskriptif yang menggambarkan efektivitas pembelajaran online (dalam jaringan) berdasarkan kriteria tujuan pendidikan dengan menggunakan beberapa tahapan seperti pengumpulan data, reduksi data, dan penyajian data.

\section{HASIL DAN PEMBAHASAN}

Permasalahan yang terjadi di dunia pendidikan dilatarbelakangi oleh munculnya pandemi Covid-19. Hal ini tidak terjadi di Indonesia saja, tetapi hampir di seluruh pelosok dunia. Penyebaran Covid-19 telah memberikan dampak negatif bagi dunia pendidikan, sehingga Surat Edaran Menteri Pendidikan dan Kebudayaan Nomor 36962/MPK.A/HK/2020 tanggal 13 Maret 2020 tentang pembelajaran dan pekerjaan yang dilakukan secara online (di jaringan) atau melakukan segala sesuatu dari rumah, sebagai upaya memutus mata rantai penyebaran Covid-19. Surat edaran tersebut merupakan respon pendidikan terhadap pandemi COVID-19. Sejak surat edaran itu dikeluarkan, semua proses belajar mengajar yang semula datang ke sekolah dan belajar di kelas, kini dialihkan melalui belajar di rumah atau lebih dikenal dengan istilah school from home. Pembelajaran online (on the network) yang dilakukan oleh setiap siswa tentunya menggunakan akses internet untuk membantu siswa dalam mengakses berbagai tugas dan informasi yang disampaikan oleh sekolah atau guru kelas kepada siswa (Tesniyadi, 2018). Selama pembelajaran online, siswa memiliki banyak waktu untuk belajar. Berbeda dengan di sekolah yang hanya dibatasi jam 07.00-12.00 untuk melaksanakan belajar mengajar yang dilakukan oleh guru dan siswa. Namun membuat siswa nyaman dalam melakukan pembelajaran di sekolah, dimana mereka bertemu dengan teman, guru, mendapatkan materi atau penjelasan langsung yang disampaikan oleh guru. Jika siswa mengalami kesulitan dalam belajar, siswa dapat langsung bertanya kepada guru atau teman di kelas yang memiliki banyak kesempatan dan waktu yang tidak terbatas untuk mengajukan pertanyaan atau pernyataan. Sedangkan kegiatan belajar mengajar yang dilakukan dari rumah atau online (dalam jaringan) tidak memberikan siswa waktu untuk bertemu langsung dengan teman dan guru, maka pembelajaran online menyulitkan mereka untuk mengakses berbagai informasi karena kendala jaringan.

Pembelajaran online merupakan sistem pembelajaran yang dilakukan tidak secara tatap muka, melainkan menggunakan platform yang dapat membantu proses belajar mengajar yang dilaksanakan walaupun jaraknya jauh. Tujuan pembelajaran online adalah untuk memberikan layanan pembelajaran yang berkualitas dalam jaringan yang masif dan terbuka untuk menjangkau lebih banyak dan lebih luas minat terhadap ruang belajar (Sofyana \& Rozaq, 2019). Namun masih ada beberapa sekolah yang memilih proses pembelajaran 
offline (di luar jaringan) dalam arti pembelajaran dilakukan secara tatap muka antara guru dan siswa dengan tetap menerapkan protokol kesehatan yang direkomendasikan oleh pemerintah. Hal ini banyak dilakukan oleh sekolah-sekolah di daerah pedesaan dan di daerah pegunungan. Guru juga dihadapkan pada berbagai kendala dalam melaksanakan pembelajaran online, mulai dari teknik pembelajaran online, menurunnya motivasi belajar siswa, kuota internet yang banyak digunakan, dan kurangnya kerjasama dari orang tua siswa. Meskipun banyak masalah yang dihadapi, guru harus tetap profesional dan bertanggung jawab atas kelangsungan proses belajar mengajar dan pencapaian tujuan pendidikan. Oleh karena itu, guru harus semaksimal mungkin membuat inovasi atau memanfaatkan media pembelajaran yang ada agar nantinya pembelajaran dapat berjalan dengan baik dan siswa dapat memahami materi dengan baik, Proses pembelajaran online masih belum maksimal. Banyaknya siswa yang tidak memiliki perangkat dan akses jaringan internet menjadi kendala paling umum dalam pelaksanaan pembelajaran jarak jauh ini. Bahkan sebagian besar dari mereka harus sengaja belajar berkelompok dan menumpang bersama teman-teman yang memiliki gadget dan akses internet (Republika, 2020).

Efektivitas atau efektivitas dalam KBBI berarti keadaan pengaruh, kesan, keberhasilan suatu usaha atau tindakan. Efektivitas adalah hubungan antara output suatu pusat pertanggungjawaban dengan target yang harus dicapai, semakin besar kontribusi dari output yang dihasilkan terhadap nilai pencapaian target tersebut maka dapat dikatakan efektif (Supriyono, 2000:29). Menurut Gibson, efektivitas adalah penilaian yang dibuat sehubungan dengan pencapaian individu, kelompok, dan organisasi. Semakin dekat pencapaiannya dengan pencapaian yang diharapkan, semakin efektif mereka dianggap (Putri, 2019: 1). Efektivitas pembelajaran adalah proses pembelajaran yang dilakukan oleh guru untuk mengubah kemampuan dan persepsi siswa dari yang sulit mempelajari sesuatu menjadi mudah dipelajari. Efektivitas program pembelajaran tidak hanya dilihat dari tingkat prestasi belajarnya saja, tetapi juga harus ditinjau dari segi proses dan fasilitas pendukungnya. Efektivitas metode pembelajaran merupakan ukuran yang berkaitan dengan tingkat keberhasilan suatu proses pembelajaran. Efektivitas dapat diukur dengan melihat minat siswa terhadap kegiatan belajar. Dalam konteks kegiatan pembelajaran perlu mempertimbangkan efektivitas, artinya sejauh mana tujuan yang telah ditetapkan dapat tercapai sesuai dengan yang diharapkan. Ciri-ciri efektivitas program pembelajaran adalah berhasil mengantarkan siswa mencapai tujuan pembelajaran yang telah ditentukan, memberikan pengalaman belajar yang menarik, melibatkan siswa secara aktif, sehingga mendukung pencapaian tujuan pembelajaran dan memiliki fasilitas yang mendukung proses belajar mengajar (Rohmawati, 2015). ). Suatu indikator sesuatu dapat dikatakan efektif jika mencapai target yang diinginkan, baik dari segi tujuan pembelajaran maupun prestasi belajar siswa yang maksimal. Beberapa indikator efektivitas pembelajaran adalah ketercapaian ketuntasan belajar, ketercapaian efektivitas kegiatan siswa (yaitu tercapainya waktu ideal yang digunakan siswa untuk melaksanakan setiap kegiatan yang terdapat dalam RPP), ketercapaian efektivitas pembelajaran. kemampuan guru dalam mengelola pembelajaran dan respon siswa terhadap pembelajaran yang positif (Sinambela, 2006: 78). Dalam konteks ini, efektivitas pembelajaran merupakan ukuran keberhasilan proses interaksi dalam situasi pendidikan untuk mencapai tujuan pembelajaran. Dengan demikian, efektivitas kegiatan belajar mengajar harus selalu ditingkatkan guna meningkatkan kualitas pendidikan itu sendiri. Seorang guru harus pandai memilih metode apa yang harus digunakan agar siswa dapat menangkap apa yang disampaikan.

Faktor pendukung dan faktor penghambat bagi guru selama pembelajaran online di masa pandemi COVID-19, dapat disimpulkan bahwa pandemi COVID19 berdampak besar bagi dunia pendidikan. Pandemi ini mengakibatkan proses pembelajaran menjadi sangat terganggu, proses pembelajaran yang biasanya dilakukan secara tatap muka antara guru dan siswa di kelas saat pandemi pembelajaran berubah menjadi pembelajaran online. Guru mengungkapkan masih banyak kendala yang dihadapi anak SD dalam pembelajaran online. Partisipasi siswa dalam pembelajaran juga belum mencapai $100 \%$ dalam pembelajaran online. Ada beberapa siswa yang bahkan tidak mengikuti pembelajaran sama sekali dari awal sampai akhir, sehingga guru merasa bingung dalam proses penilaian siswa tersebut. Proses pembelajaran online dilakukan sesuai dengan jam pembelajaran yang telah ditentukan sebelumnya. Pembelajaran online yang dilakukan oleh guru menggunakan whatsapp yang digunakan sebagai media guru dalam menyampaikan materi atau mengirimkan tugas kepada siswa. Dewi (2020:4) juga mengungkapkan bahwa pembelajaran online bisa menggunakan teknologi digital, namun yang harus dilakukan adalah memberikan tugas melalui monitoring pendampingan oleh guru melalui grup whatsapp agar anak benar-benar belajar. Guru juga harus berkoordinasi dengan orang tua, baik melalui video call maupun foto kegiatan belajar anak di rumah untuk memastikan ada interaksi antara guru dan orang tua. Guru juga melakukan video call untuk beberapa materi pembelajaran yang memerlukan penjelasan langsung. Selain itu dalam hal pemberian tugas yang diberikan terkadang tidak sesuai dengan materi yang seharusnya, hal ini dikarenakan pembelajaran online menyulitkan guru untuk berpindah dari satu materi ke materi berikutnya, namun guru berusaha memberikan tugas yang disesuaikan dengan siswa. dan buku pegangan guru. . Pembelajaran online berdampak pada siswa, dampak yang dialami siswa adalah mereka merasa sangat bosan dan bosan dengan pembelajaran. Antusiasme 
dan semangat yang ditunjukkan siswa semakin hari semakin berkurang.

Penilaian yang diberikan guru dalam pembelajaran online juga diberikan secara langsung pada saat siswa mengumpulkan tugasnya dan semua mata pelajaran juga memiliki penilaian yang sama. Guru juga menilai rasa tanggung jawab siswa jika mampu mengikuti pelajaran dan mengisi daftar hadir untuk pembelajaran online. Siswa sering mengeluh karena hanya diberikan terus menerus, padahal pada kenyataannya guru merasa tidak nyaman karena tidak dapat memberikan materi pembelajaran secara langsung kepada siswa dan hanya memberikan tugas. Cara mengatasi kebosanan tersebut, guru berinisiatif menyediakan media pembelajaran yang menarik seperti video, namun kebanyakan dalam pembelajaran online guru juga mengalami kendala atau keterbatasan dalam menggunakan media pembelajaran. Proses penilaian yang dilakukan oleh guru juga memiliki sistem yang sama dengan sistem penilaian pembelajaran pada umumnya.

Selain faktor pendukung dalam pelaksanaan pembelajaran online, juga terdapat beberapa faktor penghambat dalam pembelajaran online. Hal ini terjadi karena pembelajaran online merupakan sesuatu yang baru bagi guru. Dengan metode pembelajaran jarak jauh, guru membutuhkan waktu untuk beradaptasi dan menghadapi perubahan baru yang secara tidak langsung akan mempengaruhi kualitas hasil belajar (Purwanto et al., 2020:7). Faktor penghambatnya antara lain tidak semua siswa memiliki handphone. Faktor selanjutnya adalah adanya rasa malas pada diri siswa saat mengerjakan tugas, padahal telah ditunjang dengan fasilitas yang menunjang pembelajaran. Faktor selanjutnya adalah masih banyaknya orang tua yang bekerja sehingga tidak dapat sepenuhnya membimbing siswa dalam belajar. Ada beberapa cara untuk mengatasi kendala tersebut, di antaranya memberikan informasi di awal sebelum pembelajaran dilakukan agar pada saat pembelajaran semuanya siap mengikuti pembelajaran. Selanjutnya kerjasama dengan panitia kelas mengenai siswa yang tidak memiliki handphone untuk dapat bertanya kepada teman yang rumahnya dekat agar dapat mengikuti pembelajaran bersama. Selain itu, bagi orang tua yang sibuk bekerja, guru memberikan relaksasi dalam mengumpulkan tugas.

Pembelajaran online juga tidak lepas dari peran orang tua siswa, karena mengingat usia anak sekolah dasar yang masih membutuhkan bimbingan dan pengawasan dalam belajar. Orang tua selalu memberikan informasi baru tentang perkembangan anaknya dalam pembelajaran online. Dalam pembelajaran online, motivasi dari guru sangat dibutuhkan oleh siswa untuk menjaga semangat belajarnya. Cara guru memberikan motivasi adalah dengan memberikan tugas yang menarik dan menyenangkan dan semua guru membuat video untuk menyemangati siswa walaupun harus melaksanakan pembelajaran dari rumah.
Jaringan internet yang kurang lancar dapat menghambat pembelajaran online, seperti yang dialami oleh siswa di Dusun Beji. Hal ini dikarenakan lokasi rumah mereka berada di pedesaan, sehingga sering terjadi gangguan jaringan internet. Hal ini menjadi tantangan tersendiri dalam penerapan pembelajaran online karena syarat utama pelaksanaan pembelajaran online adalah adanya jaringan internet. Dikarenakan jaringan internet yang tidak lancar, siswa tidak memahami instruksi yang diberikan oleh guru karena informasi yang diperoleh siswa tidak lengkap dan tidak jelas. Saat guru menjelaskan, suara menjadi tidak lancar dan informasi yang diterima tidak lengkap sehingga siswa kesulitan memahami materi yang disampaikan. Jaringan internet yang tidak stabil dapat menghambat proses pembelajaran online karena internet memiliki peran penting dalam menunjang kelancaran pembelajaran jarak jauh. Keadaan ini sesuai dengan pernyataan Rosenberg mengenai kriteria dasar dalam e-learning atau pembelajaran online yaitu penyampaian yang dikirimkan kepada pengguna (siswa) melalui komputer dengan menggunakan standar teknologi internet (Yodha, 2019).

Tantangan yang dihadapi mahasiswa yang menjadi informan penelitian ini adalah mereka tidak terlalu menguasai teknologi, sehingga mereka kesulitan mengoperasikan smartphone saat belajar online. Teknologi di masa pandemi memiliki peran penting dalam kelangsungan pembelajaran online sehingga menuntut kesiapan siswa khususnya. Ada juga orang tua yang kurang memahami pembelajaran online yang dilakukan oleh anaknya. Selain itu, keterbatasan biaya penyediaan kuota internet menjadi kendala utama bagi mahasiswa. Hal ini karena mayoritas penduduk desa menganggap diri mereka sebagai kelas bawah. Pemborosan kuota internet menjadi keluhan orang tua siswa. Orang tua keberatan karena tidak mampu membeli kuota internet terus menerus untuk kebutuhan sekolah online. Bagi orang tua yang tidak bisa bekerja rutin selama wabah Corona, mereka menganggap kuota internet sebagai kemewahan karena tidak ada pemasukan finansial. Penggunaan smartphone yang hanya satu dan harus digunakan secara bergantian dengan anggota keluarga lainnya yang juga sekolah online menjadi kendala yang cukup berarti juga.

\section{SIMPULAN DAN SARAN}

\section{A. Simpulan}

Pandemi Covid-19 telah mengubah seluruh sistem ketertiban di seluruh dunia, salah satunya adalah dunia pendidikan. Pendidikan sekarang menerapkan pembelajaran yang dilakukan di rumah atau pembelajaran yang dilakukan secara online (dalam jaringan). Efektivitas pembelajaran yang dilakukan oleh lembaga pendidikan dapat dikatakan tidak efektif. Karena banyaknya kendala yang dialami oleh siswa dan guru. Beberapa faktor antara lain karena akses jaringan yang kurang memadai, kebosanan dalam belajar, keterbatasan 
penggunaan teknologi, keterbatasan sarana dan prasarana dalam biaya kuota. Oleh karena itu, banyak yang harus dipikirkan dan banyak yang harus dipersiapkan untuk menerapkan atau mendukung pembelajaran online. Dengan banyaknya kendala saat melakukan proses pembelajaran online, siswa, orang tua, bahkan guru merasa bingung dalam menghadapinya. Keterbatasan sarana dan prasarana pendukung, seperti masih banyaknya masyarakat yang belum memiliki gadget dan akses internet, serta minimnya kemampuan masyarakat dalam menggunakan teknologi digital, menambah tidak efektifnya pembelajaran online.

\section{B. Saran}

Melihat dari situasi pandemi Covid-19 yang sedang berlangsung, ada banyak hal yang harus diperhatikan dan harus diperhatikan, serta diselesaikan dalam mengatasi setiap permasalahan yang terjadi. Dalam menyelesaikan suatu masalah tidak mungkin hanya satu pihak yang melakukan intervensi, tetapi dari berbagai pihak atau campur tangan dari setiap lembaga atau masyarakat yang berperan aktif dalam mensukseskannya. Mulai dari masyarakat yang mulai mencoba peka dan melihat pandangannya terhadap tantangan zaman di era digital, serta pemerintah dan instansi terkait untuk mendistribusikan infrastruktur bagi masyarakat yang tidak mampu menjangkaunya. Koordinasi dan komunikasi satu sama lain merupakan hal terpenting dan terpenting dalam menyelesaikan suatu kendala belajar yang dilakukan secara online.

\section{DAFTAR RUJUKAN}

Abidin, Z., Hudaya, A., \& Anjani, D. (2020). EFEKTIVITAS PEMBELAJARAN JARAK JAUH PADA MASA PANDEMI COVID-19. Research and Development Journal of Education, 1(1), 131146

Astuti, M. (2021). Analisis Efektifitas Penyelenggaraan Pembelajaran Daring di Sekolah Dasar Pada Masa Pandemi Covid-19. Journal of Integrated Elementary Education, 1(1), 41-48.

Baety, D. N., \& Munandar, D. R. (2021). Analisis Efektifitas Pembelajaran Daring Dalam Menghadapi Wabah Pandemi Covid-19. EDUKATIF: JURNAL ILMU PENDIDIKAN, 3(3), 880-989.

Devi, V. S., Kurniawan, S. B., \& Rintayati, P. (2021). Efektivitas pembelajaran dalam jaringan (online learning) selama wabah covid-19 pada peserta didik kelas v sekolah dasar. Didaktika Dwija Indria, 9(2).
Dewi, W. A. F. (2020). Dampak Covid-19 terhadap implementasi pembelajaran daring di Sekolah Dasar. Edukatif: Jurnal Ilmu Pendidikan, 2(1), $55-61$

Fatih Holis Ahnaf, Farida Rochmawati, Sri Maria Utami, \& Dini Dwi Syahputri. (2021). Efektivitas Media Animasi Audio Visual dalam Kuliah Daring Keterampilan Membaca. Ainara Journal (Jurnal Penelitian Dan PKM Bidang Ilmu Pendidikan), 2(2), 72-78. https://doi.org/10.1234567/ainarajournal.v2i 2.27

Hamdani, A. R., \& Priatna, A. (2020). Efektifitas Implementasi Pembelajaran Daring (Full Online) Dimasa Pandemi Covid-19 Pada Jenjang Sekolah Dasar Di Kabupaten Subang. Didaktik: Jurnal Ilmiah PGSD STKIP Subang, 6(1), 1-9.

Hanum, F., \& Yanuarita, H. A. (2020). Efektivitas Pembelajaran Dalam Jaringan (Daring) Selama Pandemi Covid-19 Di Kabupaten Jombang. JISIP (Jurnal Ilmu Sosial dan Pendidikan), 4(4)

Hidayah, A. A. F., Al Adawiyah, R., \& Mahanani, P. A. R. (2020). Efektivitas Pembelajaran Daring di Masa Pandemi Covid-19. JURNAL SOSIAL: Jurnal Penelitian Ilmu-Ilmu Sosial, 21(2), 53-56.

Jamilah, J., \& Mulyadi, M. (2020, September). Dampak Pembelajaran Daring di Tengah Pandemi COVID 19 pada Siswa Sekolah Dasar. In Prosiding Seminar Nasional Pendidikan Biologi

Nafrin, I. A., \& Hudaidah, H. (2021). Perkembangan Pendidikan Indonesia di Masa Pandemi Covid19. Edukatif: Jurnal Ilmu Pendidikan, 3(2), 456462.

Putria, H., Maula, L. H., \& Uswatun, D. A. (2020). Analisis proses pembelajaran dalam jaringan (daring) masa pandemi covid-19 pada guru sekolah dasar. Jurnal Basicedu, 4(4), 861-870.

Telupun, D. (2020). Efektivitas Penerapan Model Pembelajaran Edutainment Untuk Memotivasi Peserta Didik Selama Pembelajaran Secara Daring Di Masa Pandemi Covid-19. Jurnal Syntax Transformation, 1(6), 254-262.

Wulandari, M. A., Arga, H. S. P., Kelana, J. B., Altaftazani, D. H., \& Ruqoyyah, S. (2020). Analisis Pembelajaran "Daring" Pada Guru Sekolah Dasar di Era Covid-19. Jurnal Ilmiah P2M STKIP Siliwangi, 7(2), 164-168. 